\title{
THE EFFICIENCY LOSS OF CAPITAL INCOME TAXATION UNDER IMPERFECT LOSS OFFSET PROVISIONS
}

\author{
SYED M. AHSAN \\ PANAGIOTIS TSIGARIS
}

CESIFo Working PAPER No. 2203

Category 1: Public Finance

JANUARY 2008
An electronic version of the paper may be downloaded
- from the SSRN website:
- from the RePEc website:
- from the CESifo website:
www.SSRN.com
Www.RePEc.org
www.CESifo-group.org/wp




\title{
THE EFFICIENCY LOSS OF CAPITAL INCOME TAXATION UNDER IMPERFECT LOSS OFFSET PROVISIONS
}

\begin{abstract}
The importance of capital loss offset provisions in a world of risk is well documented in the tax literature. However, the potential deadweight losses owing to imperfect offset has not been fully explored. This paper develops a framework whereby that investigation can be carried out and utilizes numerical simulations to investigate the size of potential losses. Results show that when the government and private sector are equally efficient in handling market risk, welfare losses owing to the absence of offset provisions could be substantial. Under plausible assumptions about attitudes towards risk and time preference, and with a capital income tax rate of forty percent, over sixty cents per dollar of tax revenue raised would be dissipated. In contrast, full loss offset would reduce that loss to approximately fourteen cents.
\end{abstract}

JEL Code: H00, H21, H22.

Keywords: capital income taxation, uncertainty, deadweight loss, loss offset provisions.

\author{
Syed M. Ahsan \\ Department of Economics \\ Concordia University \\ Montreal, Quebec \\ Canada, H3G 1 M8 \\ ahsansm@vax2.concordia.ca
}

\author{
Panagiotis Tsigaris \\ Department of Economics \\ Thompson Rivers University \\ Kamloops, British Columbia \\ Canada V2C $5 \mathrm{~N} 3$ \\ ptsigaris@tru.ca
}

January 16, 2008

We would like to acknowledge Jim Seldon and Murray Young for their valuable feedback. 


\section{Introduction}

Industrial countries generally allow losses from the sale of capital assets as offsets against taxable capital gains. Allowing a portion of any deficit as a deduction from other income and permiting net losses to be carried forward or back to previous tax years are common tax code rules. ${ }^{1}$ Whatever the rules, offset provisions reduce tax liability for investors incurring capital losses and encourage risky capital investment.

Atkinson and Stiglitz (1980) pointed out that partial rather than full loss offset provisions might be instituted because of a government's inability to distinguish between consumption and production activities and also could be desirable if individuals were able to influence relevant states of nature. Auerbach (1986) provided a dynamic analysis of taxation impacts on investment decisions and proposed a number of rationales for asymmetry, including the desire to limit firms' deduction of fictional expenses and the wish to discourage operation of unprofitable firms.

Connections between loss offset provisions and behaviour in the face of risk have been well noted in the literature, beginning with the analysis of Domar and Musgrave (1944). They observed that in the absence of offset, tax increases lessen risk-taking. Stiglitz (1969), using a more general expected utility model, confirmed the disincentive effect and it has been observed in similar models under various tax scenarios, including those of Mossin (1968), Feldstein (1969) and Ahsan (1974). ${ }^{2}$

Most studies of this genre had ignored how the public sector would deal with the revenue risk and assumed in effect the state to be risk-neutral. When dealing with capital risks, the latter assumption may well be untenable. Bulow and Summers (1984) and Gordon (1985) have argued that, especially for corporate tax revenue, government need not be any more able to bear risk than the private sector. A key implication is that the costs of and benefits from risk-taking remain entirely in the private sector. ${ }^{3}$

Early investigations of deadweight loss (DWL) owing to capital income taxation, including work by Boskin (1978), Feldstein (1978) and Summers (1981) ignored risk. Fullerton and Gordon (1983) and Slemrod (1983) incorporated risk into their analysis by replacing the tax-induced change in

\footnotetext{
${ }^{1}$ The current United States tax code allows up to $\$ 3000$ per year in capital losses to be written off against other income. Canadian losses in any one year can be applied only against gains.

${ }^{2}$ Sandmo (1985) provides a still-relevant review of taxation impacts on savings and risk-taking.

${ }^{3}$ In order to accomplish the latter, as detailed in the next section, we assume that tax revenues are returned to each taxpayer in amounts identical to revenues collected.
} 
behaviour in Harberger's classic formula by its expected value. Gordon and Wilson (1989), examining DWL under uncertainty with full loss offset, argued that in a dynamic multi-period setting the correct measure was the certainty equivalent of the lottery and concluded that in neglecting risk-aversion, previous studies had over-estimated efficiency costs.

The present analysis employs a simple two-period, two-asset, consumptionsavings model to identify and measure efficiency losses in a risky world, comparing impacts under full and imperfect loss offsets. To allow focus on the effects of alternative tax rules we assume that the public sector is no more or less efficient than the private in handling risk, that there is no asymmetric information between individuals and the government, and that all risk is borne by the private sector.

Under these conditions and assuming non-expected utility preferences, we carry out numerical simulations of impacts and welfare costs. Starting from an initial tax rate of forty percent, we determine that under plausible assumptions about investor attitudes towards risk and consumption versus savings, the welfare loss from capital income taxation without offset would be substantial, amounting to approximately sixty two cents per dollar of tax revenue or some 18 percent of savings. In contrast, the welfare loss from capital income taxation with full loss offset would be approximately fourteen cents per dollar, or just 5 percent of savings.

The contribution of the present research is twofold. First, it presents a framework within which to calculate deadweight losses generated by capital income taxation under alternative offset rules and under the plausible rule that all risks remain in the private sector. Second, it examines the impacts that attitudes towards risk and consumption substitutability each have on tax-induced behaviour, and thence on welfare, under a given offset regime. In each case, simulations are employed to demonstrate outcomes.

The remainder of the paper is organized as follows. Section II models investor decision-making. Section III uses non-expected utility preferences to value the deadweight loss from distortions owing to capital income taxation. Section IV evaluates outcomes when capital asset selling prices, and hence tax revenues, are risky. Section V examines the sensitivity of DWL to alternative parameter values and distribution assumptions. Section VI concludes. Much of the technical derivation is relegated to the Appendix. 


\section{The Portfolio - Savings Decision}

Consider an individual who works in the first period and earns a non-stochastic wage income $Y_{1}$. The household allocates this income to current consumption, denoted by $C_{1}$, and savings, $S_{1}$. Savings, $S_{1}$, can be invested in a risky asset $a_{1}$, and a riskless investment $m_{1}$ in order to provide consumption for retirement. Thus in the first period:

$$
C_{1}=Y_{1}-S_{1}=Y_{1}-\left(a_{1}+m_{1}\right)
$$

In the second period, the safe asset yields an after tax return of $(1-\tau) r$ where $\tau$ is the tax on capital income and $r$ the before tax return per unit of investment. The state of nature $i$ determines the return of the risky asset, $x_{2 i}$. A good and a bad state of nature are modeled. In the good state of nature, the risky asset yields an after tax return $x_{2 g}(1-\tau)>0$ with probability $p$ and in the bad state of nature $x_{2 b}(1-\varphi \tau)<0$ with probability $(1-p)$ per unit of investment. ${ }^{4}$ The parameter $0 \leq \varphi \leq 1$ indicates the level of offset provision. Full loss offset (FLO) occurs when $\varphi=1$. When FLO is in effect, the household pays $x_{2 g} \tau$ in taxes per unit of investment if the good state of nature occurs and is allowed a loss offset in the bad state of nature equal to $-x_{2 b} \tau$. In the case of no loss offset (NLO), $\varphi=0$, the household still pays $x_{2 g} \tau$ in taxes in the good state of nature but is not allowed to offset any losses if the bad state materilizes. A second period stochastic lump-sum transfer from the state, denoted by $G_{2 i}$ is also provided.

During retirement the households consumes $C_{2 b}$ if the bad state of nature materializes and $C_{2 g}$ if the good state occurs. ${ }^{5}$

$$
\begin{aligned}
& C_{2 b}=(1+r(1-\tau)) m_{1}+\left(1+x_{2 b}(1-\varphi \tau)\right) a_{1}+G_{2 b} \\
& C_{2 g}=(1+r(1-\tau)) m_{1}+\left(1+(1-\tau) x_{2 g}\right) a_{1}+G_{2 g}
\end{aligned}
$$

The household's preferences are described by the class of non-expected utility preferences as formulated in a two period setting by Selden (1978, 79). These preferences include the corresponding expected cardinal utility function as a special case. The household is assumed to make choices between current and certainty equivalent future consumption, $C E\left(C_{2}\right)$. The preferences are: ${ }^{6}$

\footnotetext{
${ }^{4}$ Limited liability requires that $x_{2 b}>-1$.

${ }^{5}$ There are no bequests in the model.

${ }^{6}$ See Selden $(1978,79)$ for details.
} 


$$
U\left(C_{1}, C E\left(C_{2}\right)\right)=\left[C_{1}^{\theta}+\delta C E\left(C_{2}\right)^{\theta}\right]^{1 / \theta}
$$

where the consumer's rate of time preference is reflected in the discount factor $\delta=1 /(1+\rho)$ with $\rho$ measuring the rate of time preference and the intertemporal substitutability between current and certainty equivalent future consumption is measured by $\sigma=\frac{1}{1-\theta}$.

The certainty equivalent of future consumption is given as follows:

$$
C E\left(C_{2}\right)=E\left(C_{2}^{1-\gamma}\right)^{\frac{1}{1-\gamma}}
$$

where, $\gamma$ is the relative relative risk averson parameter measuring aversion to risk taking activity. ${ }^{7}$ The household computes the certainty equivalent future consumption given its risk preferences, and then relying on the intertemporal substitutability combines current consumption with the certainty equivalent future consumption.

For a given $G_{2 i}$, the first-order condition with respect to the choice of current consumption is:

$$
C_{1}^{\theta-1}=\delta(1+r(1-\tau)) C E\left(C_{2}\right)^{(\theta+\gamma-1)} E\left(C_{2}^{-\gamma}\right)
$$

The household sets the marginal utility of current consumption equal to the future value of the marginal utility of future consumption adjusted for its risk preference. Turning to the first order condition with respect to risk taking:

$$
E\left(C_{2}^{-\gamma} \bar{z}_{2}\right)=0
$$

where $\bar{z}_{2}$ is the after tax excess return of the risky asset relative to the safe asset. In the good state of nature $\bar{z}_{2 g}=\left(x_{2 g}-r\right)(1-\tau)>0$, while in the bad state of nature $\bar{z}_{2 b}=\left(x_{2 b}(1-\varphi \tau)-(1-\tau) r\right)<0$. Equation (6) states that at the optimum the expected marginal gain from risk taking is equal to that of the riskless investment in terms of their contribution to future consumption. ${ }^{8}$

${ }^{7}$ The utility function takes on the familiar von-Neumann Morgenstern form when 1 $\gamma=\theta$. Risk neutral constant elasticity of inter-temporal substitution preferences (RINCE) developed by Farmer (1990) is observed when $\gamma=0$.

${ }^{8}$ An interior solution obtains so long as the expected return on the risky asset exceeds the return on the riskless investment. 
Since it is assumed that the government is no more (or less) efficient in handling risk we assume that tax revenue is returned to the taxpayer in the amount identical to revenues collected. This implies that the risk remains within the private sector, and hence investors ultimately bear the entire risk. Gordon justifies such an assumption as follows:

"Given that the government absorbs a sizable fraction of the risk as a result of the taxes on corporate income, one might have expected the market risk premium to fall. However, the government cannot freely dispose of the risk it bears. Individuals must ultimately bear this risk, whether through random tax rates on other income, random government expenditures, or random government deficits" (1985, p5).

Thus given optimal choices with taxes and offset provisions, the government transfers:

$$
\begin{aligned}
& G_{2 g}=\tau r\left(Y_{1}-C_{1}^{*}\right)+\tau\left(x_{2 g}-r\right) a_{1}^{*} \\
& G_{2 b}=\tau r\left(Y_{1}-C_{1}^{*}\right)+\tau\left(\varphi x_{2 b}-r\right) a_{1}^{*}
\end{aligned}
$$

where $G_{2 i}(i=g, b)$ is precisely the tax paid by a typical individual. Under this assumption appendix 1 derives the explicit optimal values of asset choice and consumption decision. The optimal values are presented below in a general form:

$$
C_{1}^{*}=c_{1}(\tau, \varphi) Y_{1} \text { and } a_{1}^{*}=a_{1}(\tau, \varphi) Y_{1}
$$

The optimal values of consumption and risky asset holdings are linear functions of the individual's endowment, $Y_{1}$. Appendix 2 proceeds to derive the optimal response of current consumption and risky asset to an increase in capital income taxation assuming all risk remain with the private sector. The responses are as follows: ${ }^{9}$

$$
\begin{aligned}
& {\frac{\partial C_{1}^{*}}{\partial \tau}{ }_{N R S}}^{*}>0 \text { if } \varphi=1 \\
& {\frac{\partial a_{1}^{*}}{\partial \tau}{ }_{N R S}<0 \text { for all values of } \varphi}<
\end{aligned}
$$

\footnotetext{
${ }^{9} \mathrm{NRS}$ stands for no risk sharing by the government. The stochastic lump sum transfer is given to the individual in the same period it was collected but at the new inter-temporal price of consumption and asset choice. This eliminates all income effects.
} 
These two expressions measure the expected change in current consumption due to a change in the tax rate and that of the risky asset under the assumption of no risk sharing by the government (NRS). ${ }^{10}$ Current consumption is encouraged, while at the same time risky asset chioce is discouraged, because the increase in the capital income tax alters the relative price of current and future consumption distorting intertemporal decisions (i.e., see equation 5 which still holds). In the case of imperfect loss offset, risky asset holdings are discouraged even more because the relative asset returns are also distorted (i.e., see equation 6). The return of the stochastic tax revenue back to the household eliminates all income effects and only substitution effects remain. Taxation has no stimulating effects on risk taking activity.

\section{The Deadweight Loss of Capital Income Taxation}

The stochastic lump sum rebate of taxes paid would not be sufficient to hold the investor on the same indifference level as prior to the imposition of the tax, because the capital income tax would entail an efficiency loss by creating a distortion in the inter-temporal price of future consumption as well as to the assets' after tax returns given partial loss offset provisions. In what follows we use the Diamond-McFadden (1974) approach to measuring the marginal deadweight loss (MDL) of capital income taxation, which quantifies the additional income (consumption in our case) required by the investor in the current period in order to remain just as well off after the tax increase and the consequent transfer payment. MDL is equal to $\frac{d L_{1}}{d \tau}{ }_{v=c}$ where $L_{1}$ is the additional consumption needed in the first period to make the household indifferent to the tax increase. Appendix 3 shows the MDL as follows:

$$
\begin{aligned}
M D L=\frac{d L_{1}}{d \tau}{ }_{v=c}=\frac{r \tau}{(1+} & r(1-\tau)) \\
& \frac{\partial C_{1}^{*}}{\partial \tau}{ }_{N R S}+ \\
& \quad \frac{\tau x_{2 b}(1-\varphi)}{(1-\tau)(1+r(1-\tau))} \frac{(1-p) C_{2 b}^{-\gamma}}{E\left(C_{2}^{-\gamma}\right)} \frac{\partial a_{1}^{*}}{\partial \tau}{ }_{N R S}
\end{aligned}
$$

\footnotetext{
${ }^{10}$ In an important extension, Gordon and Wilson (1989) argue that in a multi-period context riskiness in future decision variables cannot be measured merely by the expected value. The correct procedure would be to use the certainty equivalent of the tax-induced change in Xi. However, in the present context, all decisions are made in the current period, and hence, are unaffected by future risk considerations.
} 
The MDL is equal to the value of the tax outstanding per unit of the i-th activity multiplied by the change in the i-th activity due to the tax change. ${ }^{11}$

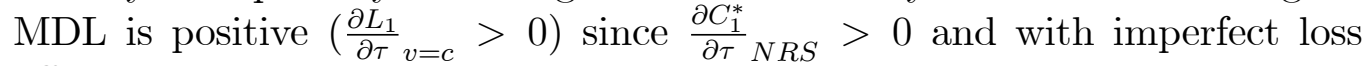
offset provisions the second term is also positive given that $x_{2 b}<0$ as well as $\frac{\partial a_{1}^{*}}{\partial \tau}{ }_{N R S}<0 .{ }^{12}$ The value of the tax outstanding per unit of consumption activity is measured by the term $\frac{r \tau}{(1+r(1-\tau))}$ and that of a risky asset choice by the term $\frac{\tau x_{2 b}(1-\varphi)}{(1-\tau)(1+r(1-\tau))}$. For the former, the quantity $(r \tau)$ is precisely the amount of tax paid on a unit of risk-less investment. This is entirely consistent with the approach of Gordon and Wilson, who explained that the "the size of the tax distortion is the same on each asset, and can be measured most simply by the taxes paid on the riskless investment" (Gordon and Wilson, p427).

The term $\frac{\tau x_{2 b}(1-\varphi)}{(1-\tau)(1+r(1-\tau))}$ reflects the distortion in the relative asset return that is associated with the partial loss offset provision of the tax code. The value of tax outstanding is equal to zero under full loss offset provision and negative under partial loss offset provisions. With full loss offset provisions there is no deadweight loss associated with the portfolio choice since the value of the tax outstanding per unit of the risky activity is equal to zero. With full loss offset provisions the deadweight loss consists only of the first right-hand term in equation (10). Furthermore, under full loss offset provisions it is the elasticity of substitution that establishes the existence of deadweight loss due to capital income taxation (given a non-zero EIS) as in the case of certainty. The relative risk aversion determines the magnitude and not the direction of the DWL figure under full loss offset provisions. In the more general case of partial loss offset provisions both the elasticity of inter-temporal substitution and the attitude towards risk play important roles.

The $M D L$ measure above does not take into account the incremental revenue raised from an increase in capital income taxation $\left(M T R=\frac{\partial T R}{\partial \tau}\right)$. In order to adjust the $M D L$ for $M T R$, the Marginal cost of public funds $(M C F)$ expression is used which is given by: ${ }^{13}$

\footnotetext{
${ }^{11}$ This measure of the marginal efficiency cost of capital income taxation under uncertainty is related the one derived by Arnold Harberger (1971). He expressed DWL as the product of a tax distortion term and a quantity measuring the tax-induced change in behaviour. The Harberger measure was developed under conditions of certainty, and later authors have interpreted the measure as applicable to behaviour under uncertainty by qualifying the tax-induced change in behavior by its expected value. The parallel between our result and that of the traditional Harberger formula is made transparent in what follows in the text.

${ }^{12} \mathrm{MDL}$ will be negative if the government is more efficient in handling risks than the private sector, leading to a marginal welfare benefit.
} 


$$
M C F=1+\frac{M D L}{M T R}
$$

By increasing marginally the capital income tax rate, additional revenue is raised to finance public expenditures (i.e., $M T R$ ) but this increase also results in an additional cost, in terms of efficiency (i.e., $M D L$ ). Thus the $M C F$ is the efficiency cost (in cents) of raising a dollar of revenue through distortionary taxation beyond that of the dollar being raised. If $M D L=0$ then this ratio is 1 . This would be valid if we had included lump sum taxes in the model. If $M D L>0$, as is the case in this model, this ratio is greater than unity.

\section{Revenue Valuation}

In this section, an expression for $M T R$ is provided which is consistent with the no risk sharing assumption. We argue that under uncertainty, the $M T R=$ $\frac{\partial C E(T R)}{\partial \tau}$ is the additional value (certainty equivalent) of the tax revenue raised by increasing marginally the capital income tax. To be consistent with the assumption that the government is just as efficient in handling aggregate risk as the private sector the standard security market line of the capital asset pricing model developed by Lintner (1965), Mossin (1966) and Sharpe (1964) is used to value the tax revenue. ${ }^{14}$ Assume that the government issues securities that have a claim on $(7 \mathrm{a})$ and $(7 \mathrm{~b})$ as reproduced below:

$$
\begin{aligned}
& G_{2 g}=\tau r\left(Y_{1}-C_{1}^{*}\right)+\tau\left(x_{2 g}-r\right) a_{1}^{*} \\
& G_{2 b}=\tau r\left(Y_{1}-C_{1}^{*}\right)+\tau\left(\varphi x_{2 b}-r\right) a_{1}^{*}
\end{aligned}
$$

where $G_{2 i}(i=g, b)$ is precisely the tax paid by a typical individual. The market value of the above stochastic revenue flow would be equal to:

$$
C E\left(G_{2}\right)=E\left(G_{2}\right)-E\left(\bar{z}_{2 m}\right) \frac{\operatorname{cov}\left(G_{2}, \bar{z}_{2 m}\right)}{\operatorname{var}\left(\bar{z}_{2 m}\right)}
$$

\footnotetext{
${ }^{13}$ Sandmo (1998) defines the MCF "as the multiplier to be applied to the direct resource cost in order to arrive at the socially relevant shadow price of resources to be used in the public sector."

${ }^{14}$ This is also consistent with the household's portfolio allocation choice as represented by equation 6 .
} 
where $\bar{z}_{2 m}$ is the after tax excess return of the market portfolio, $\operatorname{cov}\left(G_{2}, \bar{z}_{2 m}\right)$ is the covariance of the revenue flow with the excess return of the market portfolio and $\operatorname{var}\left(\bar{z}_{2 m}\right)$ is the variance. The second part of (13) is the risk premium of the uncertain tax revenue flow as determined by the asset pricing model. Substituting in (13) the lump sum transfer and after simple manipulations yields:

$$
\begin{aligned}
& C E\left(G_{2}\right)=\operatorname{\tau r}\left(Y_{1}-C_{1}^{*}\right)+\tau a_{1}^{*}\left[E\left(z_{2}\right)-E\left(\bar{z}_{2 m}\right) \frac{\operatorname{cov}\left(z_{2}, \bar{z}_{2 m}\right)}{\operatorname{var}\left(\bar{z}_{2 m}\right)}\right] \\
& C E\left(G_{2}\right)=\operatorname{\tau r}\left(Y_{1}-C_{1}^{*}\right)
\end{aligned}
$$

where $E\left(z_{2}\right)=p\left(x_{2 g}-r\right)+(1-p)\left(\varphi x_{2 b}-r\right)$ is the pre-tax excess return of the household's portfolio. The certainty equivalent of the tax revenue from capital income taxation is equal to the tax revenue generated from risk free interest on total savings, i.e., $\operatorname{\tau r}\left(Y-C_{1}^{*}\right)$. The certainty equivalent of the tax revenue generated from the excess return held by the household is zero. $^{15}$ The excess return of the security held by the investor is equal to $E\left(z_{2}\right)=E\left(\bar{z}_{2 m}\right) \frac{\operatorname{cov}\left(z_{2}, \bar{z}_{2 m}\right)}{\operatorname{var}\left(\bar{z}_{2 m}\right)}$ according to the security market line. Thus the market value of the revenue stream from the excess return equals zero. The market prices all investments. As a result the government's financial assets, which have a claim on the revenue of the excess returns, is of no value to the market because the claim does not offer to the investor any additional diversification possibilities other than those already offered by the market. Therefore, the additional revenue raised in the second period is:

$$
M T R=\frac{\partial C E\left(G_{2}\right)}{\partial \tau}=r\left(Y_{1}-C_{1}^{*}\right)-\tau r \frac{\partial C_{1}^{*}}{\partial \tau}{ }_{N R S}
$$

Substituting the present value of (16) into (11) results in:

$$
M C F=\frac{r\left(Y_{1}-C_{1}^{*}\right)+\frac{\tau x_{2 b}(1-\varphi)}{(1-\tau)(1+r(1-\tau))} \frac{(1-p) C_{22}^{-\gamma}}{E\left(C_{2}^{-\gamma}\right)} \frac{\partial a_{1}^{*}}{\partial \tau} N R S}{r\left(Y_{1}-C_{1}^{*}\right)-\tau r \frac{\partial C_{1}^{*}}{\partial \tau} N R S}
$$

The loss is the smallest when there is full loss offset provisions since the second term in the numerator is absent in this case. MCF increases as loss offset provisions are removed. The next section provides a numerical illustration of the magnitude of the deadweight loss of capital income taxation under various parameter values.

\footnotetext{
${ }^{15}$ See also Hamilton (1987), Zodrow (1995), Ahsan and Tsigaris (1998).
} 


\section{$5 \quad$ Numerical Simulations}

The parameters of the model are largely based on empirical regularities. In addition some extreme cases are examined. The relative risk aversion parameter is assumed to vary between 0 (risk neutrality) to a maximum of value of $4 .{ }^{16} \mathrm{~A}$ zero RRA value will give results for a risk neutral agent whose behaviour is governed by RINCE preferences developed by Farmer (1990). A risk neutral investor is seen to allocate the entire savings to the (on average) higher yielding risky asset. She is also allowed to borrow the safe asset. The other extreme occurs when the relative risk aversion of an investor is at the other end of the spectrum in which case she invests all savings in the safe asset. Under this case the investor would still choose the consumption stream based on the inter-temporal rate of substitution. The welfare results in this latter case will correspond to the two period model life cycle model under certainty (eg, Feldstein, 1978). The elasticity of substitution is allowed to vary between 0.00 and 2.5 .

The distribution of the asset returns is as follows. The value of the safe return is assumed to be 50 percent over a life cycle of say 25 years, which would translate to an annual compounded rate of return of 1.64 percent. This annual rate closely corresponds to the real yield on long government bonds. The rate of return of the risky asset is chosen initially to yield an average real annual rate of 5.80 percent, which is slightly higher than the real return on the S \& P 500 index of approximately 5.17 percent over the past forty years. The probability of the good state of nature is set at 80 percent. The good state of nature yields an annual return of return equal to 6.6 percent, while the bad state of nature yields an annual loss of approximately 2.7 percent. The tax rate is set initially at 40 percent.

Numerical simulations follow. Figure 1 presents the marginal tax revenue generated by increasing the capital income tax rate under the assumption of full loss-offset provision. Figure 2 illustrates the no loss-offset provision.

\footnotetext{
${ }^{16}$ Although higher RRA values can be simulated they do not provide any more insights.
} 
Figure 1: MTR under Full Loss Offset

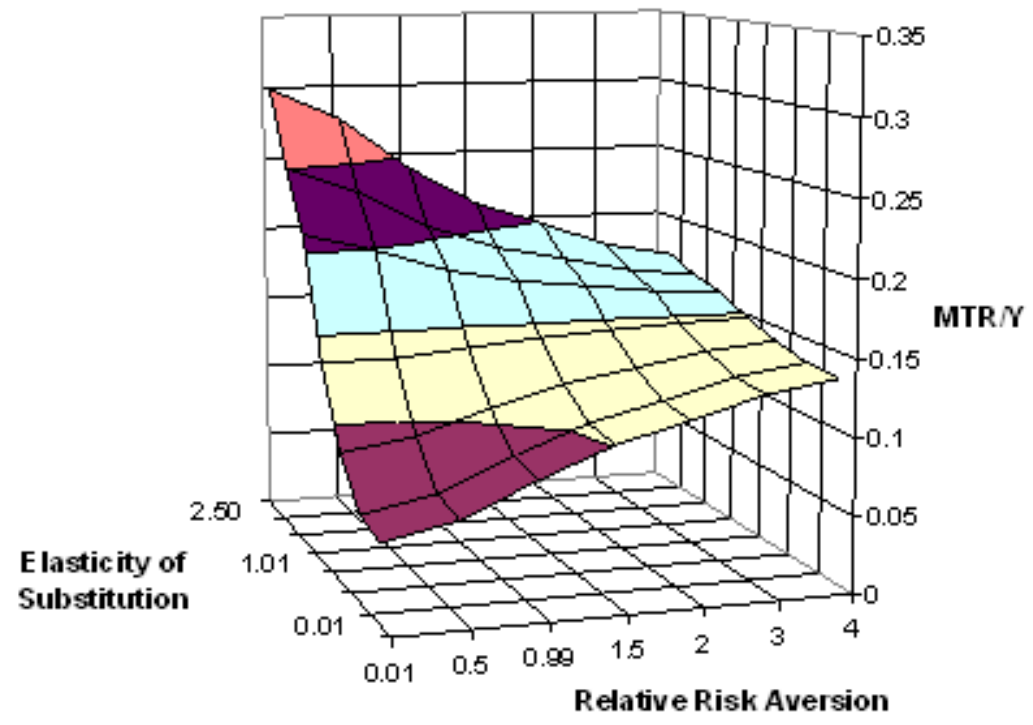

Figure 2: MTR under No Loss Offset

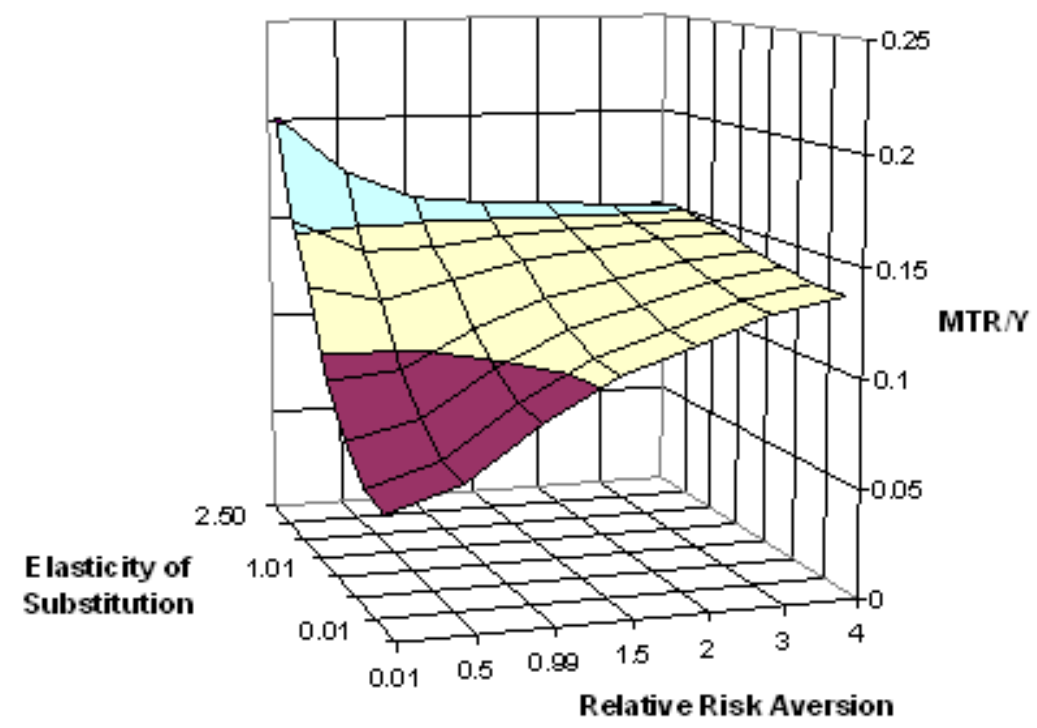

MTR under loss offset is above the no loss offset function under the same relative risk aversion and EIS parameters. Thus the government is not capable of generating more additional revenue by imposing loss offset restrictions. 
This phenomenon arises because under no loss offset provision savings are more severely discouraged than in the case of loss offset. Furthermore, MTR increases with the elasticity of intertemporal substitution, more so for low levels of risk aversion parameter. Holding the elasticity of substitution constant (and less than unity), MTR increases the with relative risk aversion parameter. In the case where the elasticity of substitution is greater than unity MTR declines as relative risk aversion parameter increases.

Figure 3: MCF under Full Loss Offset

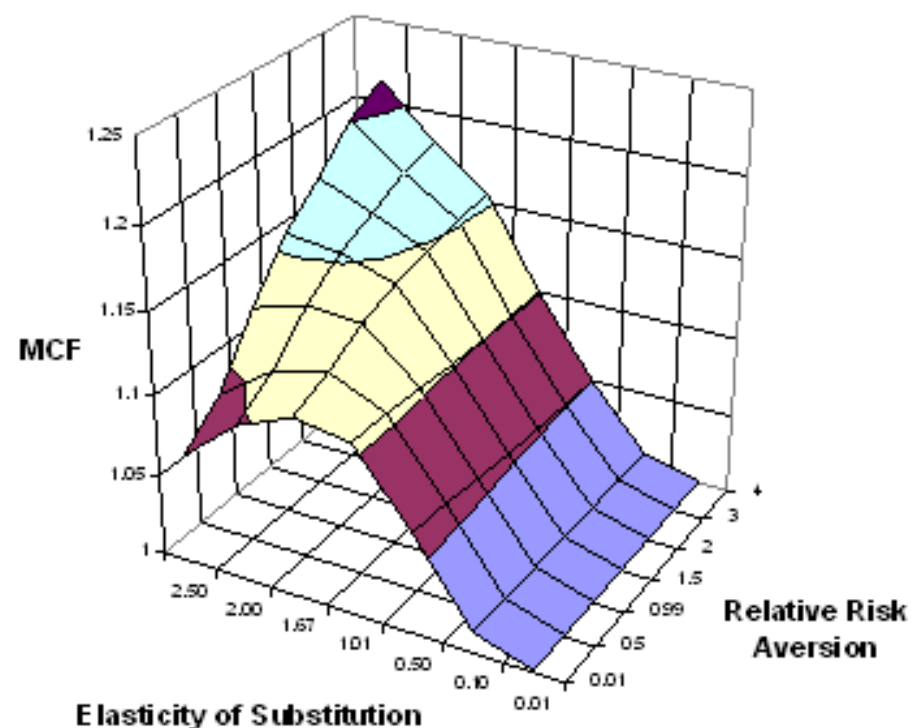

MCF ranges from the value of 1 to a maximum of 1.25 approximately. ${ }^{17}$ Figure 3 indicates that the largest MCF occurs for a person with the highest elasticity of substitution and the highest risk aversion parameter. For a representative investor with an elasticity of substitution of 1.67 and a relative risk aversion of around 2, the efficiency cost would equal fourteen cents to a dollar of revenue raised.

MCF varies with respect to EIS and RRA values.

With respect to EIS, MCF falls as the inter-temporal elasticity of substitution decreases for risk aversion parameters greater than unity. However,

\footnotetext{
${ }^{17}$ In terms of MDL relative to savings, the losses range from zero to 6.6 percent of savings in the same range of parameters. The largest deadweight losses, as a fraction of savings, occur for a person with the highest elasticity of substitution and the highest risk aversion parameter (i.e., 6.6 percent of savings). An investor with an elasticity of substitution of 1.67 and a relative risk aversion of around 2 would require compensation equal to 4.8 percent of his savings in order to be as well off as in the pre-tax position.
} 
for an individual that has a relative risk aversion less than unity, the losses peak at an inter-temporal elasticity of substitution greater than unity and then fall continuously as EIS falls.

With respect to risk aversion, MCF rises as RRA increases when the elasticity of substitution is greater than unity. MCF falls as RRA increases when the elasticity of substitution is less than or equal to unity. With a very high value of 4 for the relative risk aversion, individuals hold most of the entire fund in the safe asset, MCF is equal to 1.15 given an elasticity of inter-temporal substitution of 1.67. For the same inter-temporal substitution value, the MCF drops to 1.10 given risk neutrality. Thus under full loss offset provisions, the less risk averse an investor is, the lower the efficiency cost of capital income taxation for a given EIS.

Figure 4 below presents the results under the other extreme assumption of having no loss offset provisions. ${ }^{18}$ Under no loss offset the less risk averse an investor is, the higher the efficiency cost of capital income taxation.

\section{Figure 4: MCF under No Loss Offset}

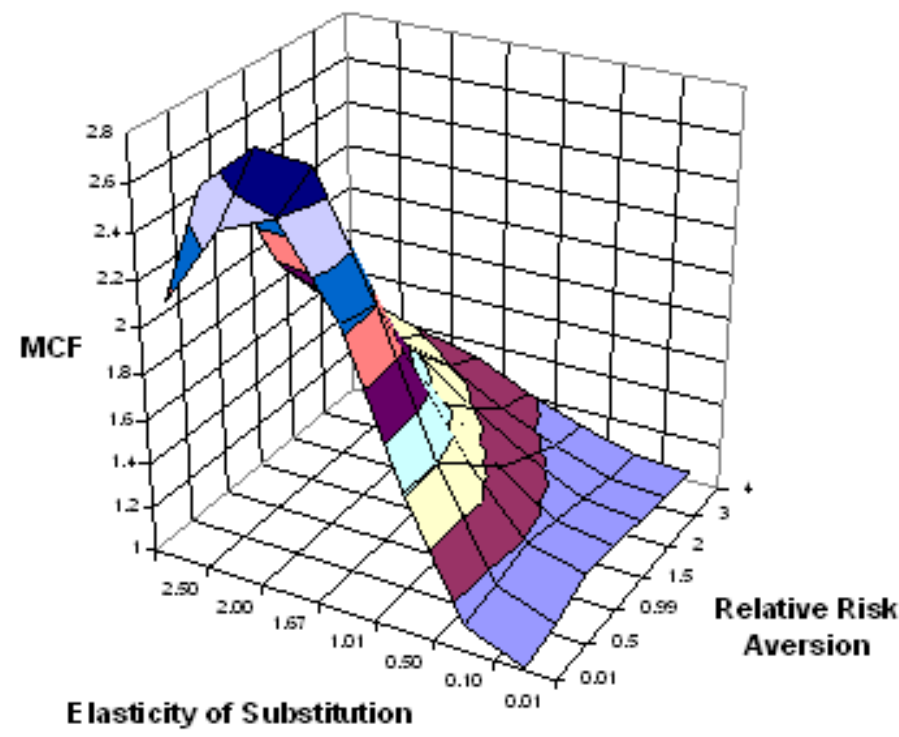

The welfare losses range from a value of unity to a maximum of 2.48 within the given range. Under no loss offset, the welfare loss is highest for

\footnotetext{
${ }^{18}$ The same MCF shape (although lower corresponding MCF values) is observed for partial loss offset provision levels up to an approximate value of $\varphi=0.80$ level beyond which the Figure 4 shape takes effect.
} 
a person that combines a high elasticity of inter-temporal substitution but is not very averse to risk taking activity. For example, a person with an elasticity of substitution of 1.67 and a relative risk aversion parameter of 0.5 will have a welfare loss equal to $\$ 2.48$ for every dollar of revenue raised. But a risk aversion parameter of 2 results in a welfare loss of capital income taxation equal to $\$ 1.62$. Contrasting this latter example with the case of full loss offset provision, the welfare loss under no loss offset increases by a magnitude of forty-eight additional cents to the dollar of revenue raised. ${ }^{19}$

Finally, Figure 5 shows the deadweight losses for a representative agent with an intertemporal elasticity of substitution of 1.67 and a relative risk aversion parameter of 2 over various tax rates and loss offset levels. As expected, the deadweight losses increase with the tax rate and with less provision to loss offsets. The DWL are at a minimum when there is full loss offset provisions and the capital income tax rate is as low as possible.

Figure 5: Welfare Losses for a "Typical" Agent

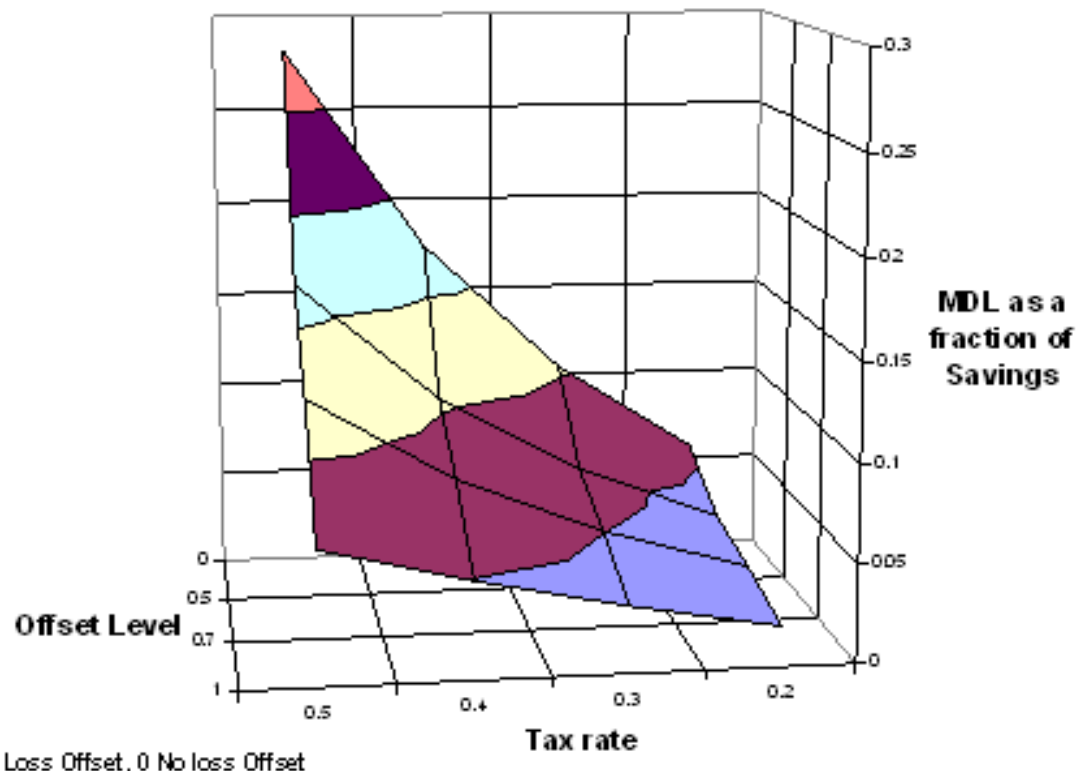

1 Full Loss Offset, 0 No loss Offset

\footnotetext{
${ }^{19}$ The welfare losses as a fraction of savings range from zero to a maximum of thirty eight percent of savings over these same parameter values. For example, a person with an elasticity of substitution of 1.67 and a relative risk aversion parameter of .5 will have a welfare loss of 38 percent! While a risk aversion parameter of 2 will have a welfare loss of capital income taxation equal to 18 percent of savings. Contrasting this later example, with the case of full loss offset provision, the welfare loss under no loss offset increases by a magnitude of four times.
} 


\section{Conclusion}

This paper has investigated deadweight losses stemming from capital income taxation in a two period model, comparing the impacts of complete and incomplete loss offset provisions. Key assumptions are that all risk remains within the private sector and that non-expected utility preferences prevail. The results indicate that capital income taxation under less than full loss offset deters risky investment activity and adds substantially to the inefficiency of taxing capital income.

Efficiency cost estimates without loss offset, under plausible assumptions about attitudes towards risk and time preference and given an initial capital income tax rate of forty percent, were shown to be on the order of sixty two cents per dollar of tax revenue. In contrast, under the same attitudes towards consumption and risk but with full loss offset, the dead weight loss was approximately fourteen cents per dollar of revenue raised.

In the absence of loss offset, efficiency costs are found to be greatest where agents have a low relative risk aversion and a high elasticity of inter-temporal substitution. With loss offset provisions in place, the welfare loss is greatest under high relative risk aversion. Finally, deadweight losses are found to increase not only with the tax rate, holding offset provisions constant, but also inversely with loss offset levels at any given tax rate.

Future research might fruitfully explore the consequences of asymmetric information between the government and investors, of the government's being more (or less) efficient in the handling risk than the private sector, and of extending the analysis to a multi-period decision framework.

\section{References}

1. Ahsan, S.M., (1974), "Progression and Risk Taking," Oxford Economic Papers, 318-28.

2. Ahsan, S. M. And P. Tsigaris, (1998), "The Design of a Consumption Tax under Capital Risk", Journal of Economics /Zeitschrift fuer Nationaloekonomie, 68(1), 53-78.

3. Atkinson A.B. And J.E. Stiglitz., (1980), "Lectures on Public Economics," McGraw Hill. 
4. Auerbach, A.J., (1986), "The Dynamic Effects of Tax Law Aymmetries," Review of Economic Studies, LIII, 205-225.

5. Boskin., M., (1978), "Taxation, Savings, and the Rate of Interest," Journal of Political Economy, 86, S3 S27.

6. Bulow, J.I. And L.H. Summers, (1984), "Taxation of Risky Assets," Journal of Political Economy, 92, 20-39.

7. Diamond, P.A. And D. L. McFadden, (1974), "Some Uses of the Expenditure Function," Journal of Public Economics, 3, 3-21.

8. Domar, E. D., And R. Musgrave, (1944), "Proportional Income Taxation and Risk Taking," Quarterly Journal of Economics, 58, 388 422.

9. FArmer, R., (1990), "RINCE Preferences", Quarterly Journal of Economics, CV, 4360.

10. Feldstein, M., (1969), "Effects of Taxation on Risk-Taking," Journal of Political Economy, 755-64.

11. Feldistein, M., (1978), "The Welfare Costs of Capital Income Taxation", Journal of Political Economy, 86, S29 S51.

12. Fullerton, D., And Gordon R., (1983), "A Re-Examination of Tax Distortions in General Equilibrium Models," in M. Feldstein, ed, Behavioral Simulation Methods in Tax Policy Analysis, Chicago: University of Chicago Press.

13. Gordon, R.H., (1985), "Taxation of Corporate Capital Income: Tax Revenues Versus Tax Distortions," Quarterly Review of Economics, C (1), 127.

14. Gordon, R.H., And J.D. Wilson, (1989), "Measuring the Efficiency Cost of Taxing Risky Capital Income," American Economic Review, 79, 427-439.

15. Hamilton, J.H., (1987), "Taxation, Savings, and Portfolio Choice in a Continuous Time Model," Public Finance, 42 (2), 264282.

16. Harberger, A., (1971), "Three Basic Postulates for Applied Welfare Economics: An Interpretive Essay," Journal of Economic Literature, 9, 785-97. 
17. Lintner,J. (1965), "The Valuation of Risk Assets and the Selection of Risky Investments in Stock Portfolios and Capital Budgets," Review of Economics and Statistics, 47, 13-37.

18. Mossin, J., (1966), "Equilibrium in a Capital Asset Pricing Market," Econometrica, 34, 768-783.

19. Mossin, J., (1968), "Taxation and Risk-Taking: An Expected Utility Approach," Economica, 35, 74-82.

20. Sandmo, A., (1985), "The Effect of Taxation on Savings and Risk Taking", in: A.J. Auerbach and M.S. Feldstein, eds, Handbook of Public Economics, Vol. I (Amsterdam, North Holland).

21. Sandmo, A., (1998), "Redistribution and the Marginal Cost of Public Funds," Journal of Public Economics, 70, 365-382.

22. Selden, L., (1978), "A New Representation of Preferences over 'Certain x Uncertain' Consumption Pairs: The 'Ordinal Certainty Equivalent' Hypothesis," Econometrica, 46, 104560.

23. Selden, L., (1979), "An OCE Analysis of the Effect of Uncertainty on Savings Under Risk Preference Independence," Review of Economic Studies, 46, 7382.

24. Sharpe, W.F., (1964), "Capital Asset Prices: A Theory of Market Equilibrium under Conditons of Risk," Journal of Finance, 19, 425442 .

25. Slemrod, J. (1983), "A General Equilibrium Model of Taxation with Endogenous Financial Behavior," in Martin S. Feldstein, ed., Behavioural Simulations Methods in Tax Policy Analysis, Chicago: University of Chicago Press, 1983.

26. Stiglitz, J.E., (1969), "The Effects of Income, Wealth and Capital Gains Taxation on Risk Taking," Quarterly Journal of Economics, 83, 263-83.

27. Summers, L., (1981), "Capital Taxation and Accumulation in a Life Cycle Growth Model," American Economic Review, 71, 53344.

28. Zodrow, G. R., (1995), "Taxation, Uncertainty and the Choice of a Consumption Tax Base", Journal of Public Economics, 58(2), 257-66. 


\section{Appendices}

\subsection{Appendix 1: Calculations leading to optimal choices:}

Given the preference structure:

$$
U\left(C_{1}, C E\left(C_{2}\right)\right)=\left[C_{1}^{\theta}+\delta E\left(C_{2}^{(1-\gamma)}\right)^{\frac{\theta}{(1-\gamma)}}\right]^{\frac{1}{\theta}}
$$

and the constraints:

$$
\begin{gathered}
C_{2 b}=(1+r(1-\tau))\left(Y_{1}-C_{1}\right)+\left(x_{2 b}(1-\varphi \tau)-(1-\tau) r\right) a_{1}+G_{2 b} \\
C_{2 g}=(1+r(1-\tau))\left(Y_{1}-C_{1}\right)+(1-\tau)\left(x_{2 g}-r\right) a_{1}+G_{2 g}
\end{gathered}
$$

Maximization of $A 1.1$ with respect to current consumption $\left(C_{1}\right)$, and the amount invested in the risky asset $\left(a_{1}\right)$ yields the first order conditions 5 and 6 in the main text.

$$
\begin{gathered}
{\left[C_{1}^{*}\right]^{\theta-1}=\delta(1+r(1-\tau)) C E\left(C_{2}\right)^{(\theta+\gamma-1)} E\left(C_{2}^{-\gamma}\right)} \\
E\left(C_{2}^{-\gamma} \bar{z}\right)=0
\end{gathered}
$$

Utilizing the two states of nature approach these optimal conditions can be re-written as follow:

$$
\begin{aligned}
& C_{1}^{\theta-1}=\delta(1+\bar{r})\left(p C_{2 g}^{1-\gamma}+(1-p) C_{2 b}^{1-\gamma}\right)^{\frac{(\theta+\gamma-1)}{1-\gamma}} E\left(p C_{2 g}^{-\gamma}+(1-p) C_{2 b}^{-\gamma}\right) \\
& p C_{2 g}^{-\gamma}\left(x_{2 g}-r\right)(1-\tau)+(1-p) C_{2 b}^{-\gamma}\left(x_{2 b}(1-\tau \varphi)-(1-\tau) r\right)=0 \\
& \text { where } \bar{r}=r(1-\tau) . \text { Using } A 1.6 \text { to solve for } C_{2 g} \text { yields: }
\end{aligned}
$$

$$
C_{2 g}=\left[-\frac{p \bar{z}_{2 g}}{(1-p) \bar{z}_{2 b}}\right]^{1 / \gamma} C_{2 b}=B_{0} C_{2 b}
$$


Inserting $A 1.7$ into using $A 1.5$ and solving for $C_{1}$ as a function of $C_{2 g}$ yields:

$$
C_{1}=A_{0} C_{2 g}
$$

where $A_{0}=\left[\delta(1+r(1-\tau)) p\left[\frac{\bar{z}_{2 g}-\bar{z}_{2 b}}{\bar{z}_{2 b}}\right]\left[p+(1-p) B_{0}^{\gamma-1}\right]^{\frac{\theta}{(1-\gamma)}}-1\right]^{\frac{1}{\theta-1}}$

The following system of equation composed of $A 1.7$ and $A 1.8$ along with the pre-budget constraints can be used to solve for $C_{1}, C_{2 g}, C_{2 b}, a_{1}$ and $m_{1}$ :

$$
\begin{aligned}
C_{1} & =A_{0} C_{2 g} \\
C_{2 g} & =B_{0} C_{2 b} \\
C_{2 b} & =(1+r)\left(Y_{1}-C_{1}\right)+z_{2 b} a_{1} \\
C_{2 g} & =(1+r)\left(Y_{1}-C_{1}\right)+z_{2 g} a_{1} \\
C_{1} & =Y_{1}-\left(a_{1}+m_{1}\right)
\end{aligned}
$$

After simple manipulations and defining $B_{1}=B_{0}\left(z_{2 g}-z_{2 b}\right)(1+r)$ and $A_{1}=A_{0}^{-1}\left(z_{2 g}-B_{0} z_{2 b}\right)$ current consumption is:

$$
C_{1}^{*}=c_{1}(\tau, \varphi) Y_{1}=\frac{B_{1}}{\left(A_{1}+B_{1}\right)} Y_{1}
$$

while risky asset allocation can be represented as follow:

$$
a_{1}^{*}=a_{1}(\tau, \varphi) Y_{1}=\frac{(1+r)\left(B_{0}-1\right)}{\left(A_{1}+B_{1}\right) A_{0}} Y_{1}
$$

\subsection{Appendix 2. Derivation of $\frac{\partial C_{1}^{*}}{\partial \tau}{ }_{N R S}$ and $\frac{\partial a_{1}^{*}}{\partial \tau}{ }_{N R S}$}

Differentiating $A 1.9$ with respect to the capital income tax yields:

$$
\begin{aligned}
& {\frac{\partial C_{1}^{*}}{\partial \tau}}_{N R S}=\frac{c_{1}(\tau, \varphi)^{2}}{B_{1}}\left[\frac{\partial A_{1}}{\partial \tau}-\frac{A_{1}}{B_{1}} \frac{\partial B_{1}}{\partial \tau}\right] Y_{1}= \\
& =\frac{c_{1}(\tau, \varphi)^{2}}{A_{0} B_{1}}\left[A_{1} \frac{\partial A_{0}}{\partial \tau}+\frac{z_{2 g}}{B_{0}} \frac{\partial B_{0}}{\partial \tau}\right] Y_{1}
\end{aligned}
$$


where

$$
\begin{aligned}
& \frac{\partial A_{0}}{\partial \tau}=\sigma \frac{r A_{0}}{(1+r(1-\tau))}- \\
& (1-\varphi) \sigma \frac{x_{2 b} A_{0}}{(1-\tau) \gamma} \frac{(1-p) B_{0}^{-(1-\gamma)}}{\left[p+(1-p) B_{0}^{-(1-\gamma)}\right]}\left[\frac{\sigma \gamma\left(1-B_{0}\right)+\frac{\bar{z}_{2 g}}{\bar{z}_{2 b}-\bar{z}_{2 g}}}{\bar{z}_{2 b}-\bar{z}_{2 g}}\right]>0
\end{aligned}
$$

and

$$
\frac{\partial B_{0}}{\partial \tau}=-(1-\varphi) \frac{x_{2 b} B_{0}}{(1-\tau) \bar{z}_{2 b} \gamma} \leq 0
$$

Under full loss offset provision $\frac{\partial B_{0}}{\partial \tau}=0$ and $\frac{\partial A_{0}}{\partial \tau}=\frac{\sigma r A_{0}}{(1+r(1-\tau))}$. Thus under full loss offset provisions, current consumption is stimulated by a tax increase as follow:

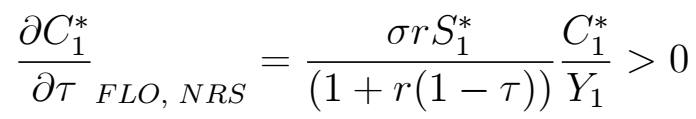

The effect gets stronger with increases in EIS $(\sigma)$. The RRA operates through its influence on average consumption and savings behavior. However under no loss offset current consumption may be discouraged in some cases since there are two opposing effects.

The effect of a tax increase on risky investment activity is given by differentiating $A 1.10$ with rspect to $\tau$ :

$$
{\frac{\partial a_{1}^{*}}{\partial \tau}{ }_{N R S}}_{=} \frac{a_{1}^{*}}{\left(B_{0}-1\right)} \frac{\partial B_{0}}{\partial \tau}-\frac{a_{1}^{*}}{\left(A_{1}+B_{1}\right)}\left[\frac{\partial A_{1}}{\partial \tau}+\frac{\partial B_{1}}{\partial \tau}\right]-\frac{a_{1}(\tau, \varphi)}{A_{0}} \frac{\partial A_{0}}{\partial \tau}
$$

This can be simplified further into the following two components:

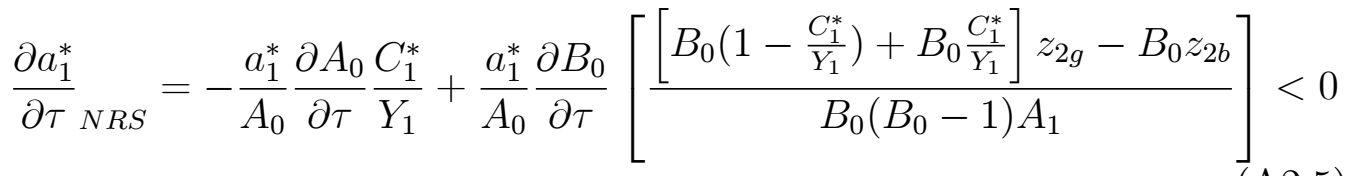

Risky asset choice is discouraged under full loss offset provisions

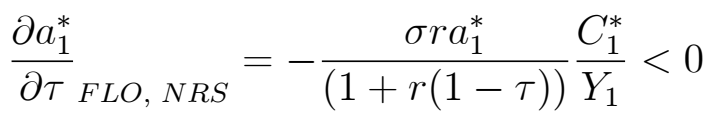

and even more so under imperfect loss offset due to the presence of the the second term in $A 2.5$. 


\subsection{Appendix 3. Calculations leading to $\mathrm{MDL}=\frac{\partial L_{1}}{\partial \tau}$ :}

The standard measure of marginal deadweight loss is the additional transfer the individual would have to receive in the first period to compensate her for the effects of the tax increase. To find the deadweight loss of capital income taxation, we differentiate the value function with respect to the tax rate and substitute the first-order conditions. The value function is:

$$
V=U\left(C_{1}^{*}+L_{1}, C E\left(C_{2}\right)^{*}\right)=\left[\left(C_{1}^{*}+L_{1}\right)^{\theta}+\delta E\left(C_{2}^{(1-\gamma)}\right)^{\frac{\theta}{(1-\gamma)}}\right]^{\frac{1}{\theta}}
$$

where the optimal choices are given in section 8.1 of the appendix and where $L_{1}$ represents the first period consumption transfer a household would require in order to be as well off as before the capital income tax. Therefore

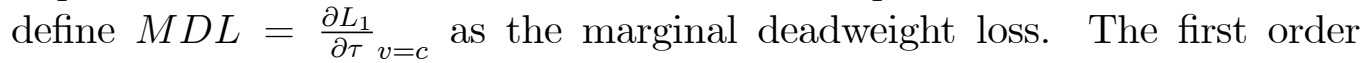
condition for consumption allocation given the stochastic lump sum transfer and the first period transfer is:

$$
\left[C_{1}^{*}+L_{1}\right]^{\theta-1}=\delta(1+r(1-\tau)) C E\left(C_{2}\right)^{(\theta+\gamma-1)} E\left(C_{2}^{-\gamma}\right)
$$

while, that of asset allocation is:

$$
E\left(C_{2}^{-\gamma} \bar{z}\right)=0
$$

Utilizing the budget constraint after re-distribution of the tax revenue $C_{2}=(1+r)\left(Y_{1}-C_{1}^{*}\right)+z a_{1}^{*}$ and differentiating the value function $A 3.1$ with respect to $\tau$ and setting the result equal to zero yields:

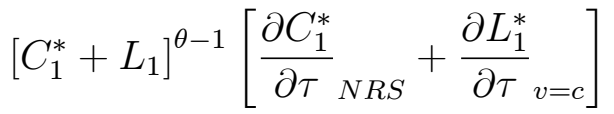

$$
\begin{aligned}
& +\delta C E\left(C_{2}\right)^{(\theta+\gamma-1)} E\left[C_{2}^{-\gamma}\left[-(1+r) \frac{\partial C_{1}^{*}}{\partial \tau}{ }_{N R S}+z \frac{\partial a_{1}^{*}}{\partial \tau}{ }_{N R S}\right]\right]=0
\end{aligned}
$$

After simple manipulation, and utilizing the first order conditions the efficiency loss quantity can be written in terms of compensating variation as in the text. 


\section{CESifo Working Paper Series}

for full list see www.cesifo-group.org/wp

(address: Poschingerstr. 5, 81679 Munich, Germany, office@cesifo.de)

2140 Lorenzo Cappellari, Paolo Ghinetti and Gilberto Turati, On Time and Money Donations, November 2007

2141 Roel Beetsma and Heikki Oksanen, Pension Systems, Ageing and the Stability and Growth Pact, November 2007

2142 Hikaru Ogawa and David E. Wildasin, Think Locally, Act Locally: Spillovers, Spillbacks, and Efficient Decentralized Policymaking, November 2007

2143 Alessandro Cigno, A Theoretical Analysis of the Effects of Legislation on Marriage, Fertility, Domestic Division of Labour, and the Education of Children, November 2007

2144 Kai A. Konrad, Mobile Tax Base as a Global Common, November 2007

2145 Ola Kvaløy and Trond E. Olsen, The Rise of Individual Performance Pay, November 2007

2146 Guglielmo Maria Caporale, Yannis Georgellis, Nicholas Tsitsianis and Ya Ping Yin, Income and Happiness across Europe: Do Reference Values Matter?, November 2007

2147 Dan Anderberg, Tax Credits, Income Support and Partnership Decisions, November 2007

2148 Andreas Irmen and Rainer Klump, Factor Substitution, Income Distribution, and Growth in a Generalized Neoclassical Model, November 2007

2149 Lorenz Blume, Jens Müller and Stefan Voigt, The Economic Effects of Direct Democracy - A First Global Assessment, November 2007

2150 Axel Dreher, Pierre-Guillaume Méon and Friedrich Schneider, The Devil is in the Shadow - Do Institutions Affect Income and Productivity or only Official Income and Official Productivity?, November 2007

2151 Valentina Bosetti, Carlo Carraro, Emanuele Massetti and Massimo Tavoni, International Energy R\&D Spillovers and the Economics of Greenhouse Gas Atmospheric Stabilization, November 2007

2152 Balázs Égert and Dubravko Mihaljek, Determinants of House Prices in Central and Eastern Europe, November 2007

2153 Christa Hainz and Hendrik Hakenes, The Politician and his Banker, November 2007

2154 Josef Falkinger, Distribution and Use of Knowledge under the "Laws of the Web", December 2007 
2155 Thorvaldur Gylfason and Eduard Hochreiter, Growing Apart? A Tale of Two Republics: Estonia and Georgia, December 2007

2156 Morris A. Davis and François Ortalo-Magné, Household Expenditures, Wages, Rents, December 2007

2157 Andreas Haufler and Christian Schulte, Merger Policy and Tax Competition, December 2007

2158 Marko Köthenbürger and Panu Poutvaara, Rent Taxation and its Intertemporal Welfare Effects in a Small Open Economy, December 2007

2159 Betsey Stevenson, Title IX and the Evolution of High School Sports, December 2007

2160 Stergios Skaperdas and Samarth Vaidya, Persuasion as a Contest, December 2007

2161 Morten Bennedsen and Christian Schultz, Arm's Length Provision of Public Services, December 2007

2162 Bas Jacobs, Optimal Redistributive Tax and Education Policies in General Equilibrium, December 2007

2163 Christian Jaag, Christian Keuschnigg and Mirela Keuschnigg, Pension Reform, Retirement and Life-Cycle Unemployment, December 2007

2164 Dieter M. Urban, Terms of Trade, Catch-up, and Home Market Effect: The Example of Japan, December 2007

2165 Marcelo Resende and Rodrigo M. Zeidan, Lionel Robbins: A Methodological Reappraisal, December 2007

2166 Samuel Bentolila, Juan J. Dolado and Juan F. Jimeno, Does Immigration Affect the Phillips Curve? Some Evidence for Spain, December 2007

2167 Rainald Borck, Federalism, Fertility and Growth, December 2007

2168 Erkki Koskela and Jan König, Strategic Outsourcing, Profit Sharing and Equilibrium Unemployment, December 2007

2169 Egil Matsen and Øystein Thøgersen, Habit Formation, Strategic Extremism and Debt Policy, December 2007

2170 Torben M. Andersen and Allan Sørensen, Product Market Integration and Income Taxation: Distortions and Gains from Trade, December 2007

2171 J. Atsu Amegashie, American Idol: Should it be a Singing Contest or a Popularity Contest?, December 2007

2172 Patricia Apps and Ray Rees, Household Models: An Historical Perspective, December 2007 
2173 Ben Greiner, Axel Ockenfels and Peter Werner, The Dynamic Interplay of Inequality and Trust - An Experimental Study, December 2007

2174 Michael Melvin and Magali Valero, The Dark Side of International Cross-Listing: Effects on Rival Firms at Home, December 2007

2175 Gebhard Flaig and Horst Rottmann, Labour Market Institutions and the Employment Intensity of Output Growth. An International Comparison, December 2007

2176 Alexander Chudik and M. Hashem Pesaran, Infinite Dimensional VARs and Factor Models, December 2007

2177 Christoph Moser and Axel Dreher, Do Markets Care about Central Bank Governor Changes? Evidence from Emerging Markets, December 2007

2178 Alessandra Sgobbi and Carlo Carraro, A Stochastic Multiple Players Multi-Issues Bargaining Model for the Piave River Basin, December 2007

2179 Christa Hainz, Creditor Passivity: The Effects of Bank Competition and Institutions on the Strategic Use of Bankruptcy Filings, December 2007

2180 Emilia Del Bono, Andrea Weber and Rudolf Winter-Ebmer, Clash of Career and Family: Fertility Decisions after Job Displacement, January 2008

2181 Harald Badinger and Peter Egger, Intra- and Inter-Industry Productivity Spillovers in OECD Manufacturing: A Spatial Econometric Perspective, January 2008

2182 María del Carmen Boado-Penas, Salvador Valdés-Prieto and Carlos Vidal-Meliá, the Actuarial Balance Sheet for Pay-As-You-Go Finance: Solvency Indicators for Spain and Sweden, January 2008

2183 Assar Lindbeck, Economic-Social Interaction in China, January 2008

2184 Pierre Dubois, Bruno Jullien and Thierry Magnac, Formal and Informal Risk Sharing in LDCs: Theory and Empirical Evidence, January 2008

2185 Roel M. W. J. Beetsma, Ward E. Romp and Siert J. Vos, Intergenerational Risk Sharing, Pensions and Endogenous Labor Supply in General Equilibrium, January 2008

2186 Lans Bovenberg and Coen Teulings, Rhineland Exit?, January 2008

2187 Wolfgang Leininger and Axel Ockenfels, The Penalty-Duel and Institutional Design: Is there a Neeskens-Effect?, January 2008

2188 Sándor Csengődi and Dieter M. Urban, Foreign Takeovers and Wage Dispersion in Hungary, January 2008

2189 Joerg Baten and Andreas Böhm, Trends of Children's Height and Parental Unemployment: A Large-Scale Anthropometric Study on Eastern Germany, 1994 2006, January 2008 
2190 Chris van Klaveren, Bernard van Praag and Henriette Maassen van den Brink, A Public Good Version of the Collective Household Model: An Empirical Approach with an Application to British Household Data, January 2008

2191 Harry Garretsen and Jolanda Peeters, FDI and the Relevance of Spatial Linkages: Do third Country Effects Matter for Dutch FDI?, January 2008

2192 Jan Bouckaert, Hans Degryse and Theon van Dijk, Price Discrimination Bans on Dominant Firms, January 2008

2193 M. Hashem Pesaran, L. Vanessa Smith and Takashi Yamagata, Panel Unit Root Tests in the Presence of a Multifactor Error Structure, January 2008

2194 Tomer Blumkin, Bradley J. Ruffle and Yosef Ganun, Are Income and Consumption Taxes ever really Equivalent? Evidence from a Real-Effort Experiment with Real Goods, January 2008

2195 Mika Widgrén, The Impact of Council's Internal Decision-Making Rules on the Future EU, January 2008

2196 Antonis Adam, Margarita Katsimi and Thomas Moutos, Inequality and the Import Demand Function, January 2008

2197 Helmut Seitz, Democratic Participation and the Size of Regions: An Empirical Study Using Data on German Counties, January 2008

2198 Theresa Fahrenberger and Hans Gersbach, Minority Voting and Long-term Decisions, January 2008

2199 Chiara Dalle Nogare and Roberto Ricciuti, Term Limits: Do they really Affect Fiscal Policy Choices?, January 2008

2200 Andreas Bühn and Friedrich Schneider, MIMIC Models, Cointegration and Error Correction: An Application to the French Shadow Economy, January 2008

2201 Seppo Kari, Hanna Karikallio and Jukka Pirttilä, Anticipating Tax Change: Evidence from the Finnish Corporate Income Tax Reform of 2005, January 2008

2202 Walter Krämer and André Güttler, On Comparing the Accuracy of Default Predictions in the Rating Industry, January 2008

2203 Syed M. Ahsan and Panagiotis Tsigaris, The Efficiency Loss of Capital Income Taxation under Imperfect Loss Offset Provisions, January 2008 